\title{
RANCANG BANGUN PROTOTYPE PADA APLIKASI E-COMMERCE BERBASIS WAP
}

\author{
Iman Dhermawan ${ }^{a}$, Rendra Bomantara ${ }^{b}$ \\ Universitas Muhammadiyah Magelang
}

\begin{abstract}
ABSTRAK
Entering the era of globalization, the use of information technology in all areas of daily life cannot be avoided. There are at least two technologies that have developed rapidly in the last few years for the lives of millions of people, namely the internet and cell phones. By combining these two technologies, technology is created that makes it possible to access information that does not depend on the information source and location of access, namely WAP.

Along with the development of the combination of the two technologies, several business owners began to use it. One of them is the Podomoro Notebook Store, which is located at SCC Plaza Simpang Lima, Fl. V No. 62 Semarang which is engaged in selling notebooks is trying to use it. There are several things that might encourage this application to be used, including in terms of notebook sales. The absence of an application regarding ordering goods online is also an obstacle for the shop.

The solution to solving the problem of this case is to create a wap-based information system for ordering goods. With the wap-based information system, it is hoped that it will help a little in terms of sales and this system can help to order goods online.
\end{abstract}

Key word : Information Systems, WAP, Macromedia Dreamwever, Podomoro Notebook Store, Online

\begin{abstract}
Abstrak
Memasuki era globalisasi, pemakaian teknologi informasi dalam segala bidang kehidupan seharihari tidak akan dapat dihindari. Setidaknya ada dua teknologi yang berkembang pesat beberapa tahun terakhir terhadap kehidupan jutaan manusia, yaitu internet dan ponsel. Melalui penggabungan dua teknologi tersebut terciptalah teknologi yang memungkinkan untuk mengakses informasi yang tidak tergantung pada sumber informasi dan lokasi akses yaitu WAP.

Seiring dengan berkembangnya penggabungan dua teknologi tersebut maka beberapa pemilik usaha mulai menggunakannya. Salah satunya Toko Podomoro Notebook yang beralamatkan di SCC Plaza Simpang Lima Lt. V No. 62 Semarang yang bergerak dalam bidang penjualan notebook mencoba untuk menggunakannya. Ada beberapa hal yang mungkin mendorong aplikasi ini dapat digunakan, diantaranya dari segi penjualan notebook. Belum adanya aplikasi seputar pemesanan barang secara online juga menjadi kendala bagi pihak toko.

Solusi pemecahan masalah dari kasus tersebut adalah dengan membuat sistem informasi pemesanan barang berbasis wap. Dengan adanya sistem informasi berbasis wap diharapkan akan sedikit membantu segi penjualan serta sistem ini bisa membantu untuk pemesanan barang secara online.
\end{abstract}

Kata Kunci: Sistem Informasi, WAP, Macromedia Dreamwever, Toko Podomoro Notebook, Online

\section{Pendahuluan}

Memasuki era globalisasi, pemakaian teknologi informasi dalam segala bidang kehidupan seharihari tidak akan dapat dihindari. Bahkan penggunaan teknologi tersebut akan menjadi syarat utama untuk menunjukkan kualitas suatu bidang dan menjadi modal terpenting dalam memenangkan persaingan. Setidaknya ada dua teknologi yang berkembang pesat beberapa tahun terakhir terhadap kehidupan jutaan manusia, yaitu internet dan ponsel. Penggabungan dua teknologi tersebut memungkinkan untuk mengakses informasi yang tidak tergantung pada sumber informasi dan lokasi akses.

WAP atau Wireless Application Protocol adalah suatu aplikasi yang dapat menampilkan informasi seperti halnya halaman website dengan menggunakan sebuah handphone, PDA (Personal Data Assistant), dan perangkat wireless lainnya. Ponsel dengan fasilitas Wireless Application Protocol (WAP) memungkinkan untuk mendapatkan informasi terkini dari internet. Selain itu dengan menggunakan WAP,

Received September 24, 2021; Revised Oktober 2, 2021; Accepted Oktober 22, 2021 
pemakai dapat mengakses informasi dari suatu server WAP hanya dengan menggunakan perangkat telepon selular, karena sifatnya yang mobile maka dimana dan kapan saja memungkinkan untuk dapat mengakses informasi yang diinginkan.

Seiring dengan berkembangnya penggabungan dua teknologi tersebut maka beberapa pemilik usaha mulai menggunakannya. Salah satunya Toko Podomoro Notebook yang beralamatkan di SCC Plaza Simpang Lima Lt. V No. 62 Semarang yang bergerak dalam bidang penjualan notebook mencoba untuk menggunakannya. Ada beberapa hal yang mungkin mendorong aplikasi ini dapat digunakan, diantaranya dari segi penjualan notebook. Dilihat dari tabel dibawah ini bisa disimpulkan bahwa penjualan notebook selama 3 bulan terakhir perlu adanya bantuan dari suatu aplikasi, karena grafik penjualan notebook seakan statis atau kurang dinamis setiap bulannya.

Tabel 1 Daftar Penjualan Barang Bulan Januari - Maret 2012

\begin{tabular}{|c|l|l|c|c|c|}
\hline \multirow{2}{*}{ No } & \multicolumn{1}{|c|}{ Jenis Barang } & \multicolumn{1}{|c|}{ Seri Barang } & \multicolumn{3}{c|}{ Penjualan Barang } \\
\cline { 4 - 6 } & & & Jan & Feb & Mar \\
\hline 1 & Netbook & Asus 1015 CX & 15 & 17 & 20 \\
\hline 2 & Netbook & Asus 1015 BX & 20 & 18 & 20 \\
\hline 3 & Netbook & Asus 1025 C & 10 & 10 & 17 \\
\hline 4 & Netbook & Asus 1215 B & 25 & 20 & 20 \\
\hline 5 & Notebook & Asus X44H & 10 & 15 & 15 \\
\hline 6 & Notebook & Asus A44H & 15 & 15 & 20 \\
\hline 7 & Notebook & Asus A43SJ Dual Core & 25 & 25 & 30 \\
\hline 8 & Notebook & Asus A43SJ Core i3 & 20 & 25 & 28 \\
\hline 9 & Notebook & Asus N43SL & 15 & 10 & 10 \\
\hline 10 & Notebook & Asus U36SD & 4 & 5 & 4 \\
\hline 11 & Netbook & Toshiba NB520 & 10 & 12 & 15 \\
\hline 12 & Notebook & Toshiba L740 i3 380 & 15 & 10 & 10 \\
\hline 13 & Notebook & Toshiba L745 i3 2350 & 8 & 10 & 10 \\
\hline 14 & Notebook & Toshiba L745 i3 W7 & 10 & 8 & 14 \\
\hline 15 & Notebook & Toshiba L745 i3 VGA W7 & 5 & 4 & 0 \\
\hline 16 & Notebook & Toshiba L745 i5 2450 & 4 & 0 & 5 \\
\hline 17 & Notebook & Toshiba L745 i5 W7 & 8 & 10 & 10 \\
\hline 18 & Notebook & Toshiba L745 i5 VGA W7 & 10 & 5 & 8 \\
\hline 19 & Notebook & Toshiba L745 i7 VGA W7 & & 3 \\
\hline 20 & Notebook & Toshiba C640 & & 5 & 3 \\
\hline
\end{tabular}

Sumber : Toko Podomoro Notebook

Belum adanya aplikasi yang memuat informasi seputar pemesanan barang secara online pada Toko Podomoro Notebook sehingga konsumen sering telepon terlebih dahulu atau langsung bertanya ke toko untuk memastikan kondisi barangnya.

Pihak Toko Podomoro Notebook juga belum bisa memanfaatkan teknologi telepon selular sebagai sarana mobile commerce (m-commerce) untuk memasarkan produk-produknya pada media mobile.

Untuk melakukan pengecekan stok barang, pemilik toko biasanya menggunakan sarana telepon bila sedang tidak ditoko. Hal ini tidak efisien dan tidak efektif. Selain itu juga proses pengambilan keputusan menjadi lebih lama karena pemilik toko tidak dapat mengakses keadaan usahanya secara langsung.

\section{Landasan Teori}

1. Pengertian Perancangan

Perancangan merupakan tahap penerjemahan dari keperluan atau data yang telah dianalisis ke dalam bentuk yang mudah dimengerti oleh pemakai. Ada tiga atribut yang penting dalam proses perancangan, yaitu : struktur data, arsitektur perangkat lunak, dan prosedur rinci.

2. Pengertian Pendidikan

Pendidikan adalah usaha sadar dan terencana untuk mewujudkan suasana belajar dan proses pembelajaran agar peserta didik secara aktif mengembangkan potensi dirinya untuk memiliki 
kekuatan spiritual keagamaan, pengendalian diri, kepribadian, kecerdasan, akhlak mulia, serta ketrampilan yang diperlukan dirinya, masyarakat, bangsa dan negara (UU RI nomor 20,2003).

3. Pengertian Penerimaan Siswa Baru (PSB)

Penerimaan Siswa Baru (PSB) adalah proses seleksi administrasi dan akademis calon siswa untuk memasuki jenjang pendidikan setingkat lebih tinggi (UU RI nomor 20,2003).

4. Pengertian Ujian Nasional

Ujian Nasional adalah kegiatan penilaian hasil belajar siswa yang telah menyelesaikan jenjang pendidikan dan diselenggarakan secara nasional (UU RI nomor 20,2003).

5. Pengertian Nilai Ujian Nasional

Nilai Ujian Nasional adalah nilai yang diperoleh dari hasil ujian nasional yang selanjutnya disingkat NUN (UU RI nomor 20,2003).

6. Pengertian Ijazah

Ijazah adalah surat pernyataan resmi dan sah yang menyatakan bahwa seseorang peserta didik telah menyelesaikan suatu jenjang pendidikan dan diberikan setelah dinyatakan lulus Ujian Nasional dan Ujian Sekolah (UU RI nomor 20,2003).

7. Pengertian Siswa

Siswa adalah peserta didik pada SMP, SMA dan SMK (UU RI nomor 20,2003).

8. Pengertian Seleksi

Seleksi adalah penyaringan calon siswa berdasarkan persyaratan yang telah ditetapkan (UU RI nomor 20,2003).

\section{Metodologi}

\section{Mekanisme Proses Penjualan}

Mekanisme proses penjualan merupakan aliran proses kerja yang menggunakan sistem secara garis besar. Dari hasil penelitian yang telah dilakukan dapat dijelaskan mekanisme sistem penjualan pada Toko Podomoro Notebook sebagai berikut.

Mekanisme proses penjualan pada Toko Podomoro Notebook Semarang adalah konsumen datang langsung ke toko, konsumen mencari barang, dan apabila barang yang dicari konsumen ada maka transaksi dapat diteruskan kemudian dilanjutkan dengan pencatatan transaksi penjualan. Jika barang yang dicari tidak ada, maka setelah pencarian barang proses selesai.

Sedangkan untuk mekanisme pembelian barang dimulai apabila stok barang telah habis kemudian akan memesan pada supplier dan terjadi transaksi pembelian dengan supplier dilanjutkan dengan pencatatan transaksi pembelian serta pembuatan laporan pembelian kemudian proses selesai.

\section{Analisis Sistem}

Analisis sistem adalah penguraian suatu sistem informasi yang utuh ke dalam bagian - bagian komponennya dengan maksud untuk mengidentifikasi dan mengevaluasi permasalahan - permasalahan, kesempatan - kesempatan, hambatan - hambatan yang terjadi dan kebutuhan - kebutuhan yang diharapkan sehingga dapat diusulkan perbaikannya.

Tujuan dari analisis sistem ini untuk memperbaiki beberapa fungsi didalam sistem agar bisa berjalan secara efisien. Dalam analisis sistem ini terdapat langkah - langkah dasar yang harus dilakukan yaitu :

a. Identify, yaitu mengidentifikasi masalah yang sedang terjadi

Hasil penelitian yang dilaksanakan mengenai sistem penjualan pada toko Podomoro Notebook, penulis menemukan beberapa permasalahan yang ada antara lain :

1) Belum adanya aplikasi yang memuat informasi seputar pemesanan barang secara online dan mudah diakses dengan perangkat bergerak pada Toko Podomoro Notebook.

2) Pihak Toko Podomoro Notebook belum memanfaatkan teknologi telepon selular sebagai sarana $m$-commerce.

3) Dalam pengecekan stok barang, biasanya pemilik toko menggunakan sarana telepon bila tidak sedang ditoko sehingga kurang efektif dan efisien.

b. Understand, yaitu memahami dari sistem kerja yang sudah ada.

c. Analyze, yaitu menganalis sistem

d. Report, yaitu membuat laporan hasil analisis

\section{Analisis Data}

RANCANG BANGUN PROTOTYPE PADA APLIKASI E-COMMERCE BERBASIS WAP 
*Iman Dhermawana dkk / Jurnal IImiah Teknik Mesin, Elektro dan Komputer Vol 1 No. 3 (2021) 45 - 57

Proses penganalisisan data yang dilakukan oleh peneliti yaitu data - data yang didapatkan dari observasi dan wawancara langsung dengan pengelola beserta karyawan Toko Podomoro Notebook. Dari hasil observasi dan wawancara langsung dapat disimpulkan bahwa sistem penjualan barang di Toko Podomoro Notebook ini dilakukan secara manual yaitu dilakukan pada saat calon pembeli memilih produk notebook yang ingin dibeli maupun dengan katalog notebook yang telah tersedia untuk jenis notebook atau netbook dan apabila barang yang dicari konsumen ada maka transaksi dapat diteruskan kemudian dilanjutkan dengan pencatatan transaksi penjualan. Jika barang yang dicari tidak ada, maka setelah pencarian barang proses selesai.

Selain itu pihak karyawan Toko Podomoro Notebook juga masih menggunakan asas kepercayaan melalui via telepon tanpa adanya bukti tertulis kesepakatan pemesanan, maka dari itu sistem pemesanan dan penjualan notebook atau netbook yang sudah berjalan selama ini dinilai kurang sejalan dengan tuntutan dan juga kemajuan teknologi saat ini.

Maka dari itu diperlukannya sistem baru berbasis web mobile yang diharapkan akan sangat bermanfaat dalam hal publikasi, dan juga sistem informasi di Toko Podomoro Notebook.

\subsection{Bahan Penelitian}

1. Identifikasi hadware

Hadware atau perangkat keras adalah komponen computer yang mempunyai computer yang mempunyai bentuk fisik.penulis akan mengusuhkan beberapa hadware dibawah ini, alasan pemilih hadware tersebut agar dapat menunjang jalannya system sehingga lebih nyaman dan lebih cermat. Berikut hardware yang diusulkan pada sistem yang dijalankan:

$\begin{array}{llll}\text { a. Processor } & : & \text { Pentium } 4 \\ \text { b. RAM } & : & 512 \mathrm{MB} \\ \text { c. CD ROM/RW } & : & 52 \mathrm{X} \\ \text { d. Floppy Drive } & : & 3.5,1.44 \mathrm{Mb} \\ \text { e. Hard Disk } & : & 40 \mathrm{~Gb} \\ \text { f. Monitor } & : & 15^{\prime} \mathrm{SVGA} \\ \text { g. Mouse \& Keyboard } & : & \text { Serial / PS2 } \\ \text { h. Modem } & : & 128 \mathrm{Kbps}\end{array}$

2. Identifikasi Software

Untuk menjalankan aplikasi ini,software yang digunakan yaitu

a. PHP ( Hypertext Preprocessor).

b. Macromedia Dreamweaver MX 2004

c. MySQL Server, Apache

d. Adobe Photoshop

\subsection{Desain Penelitian}

Gambar 1 berikut merupakan arsitektur dari context diagram yang menggambarkan perancangan sistem baru. Entitas yang terkait meliputi Calon siswa, Panitia dan Kepala sekolah.

JURNAL ILMIAH TEKNIK MESIN, ELEKTRO DAN KOMPUTER Vol.1, No.3, November 2021, pp. 45 - 57 
*Iman Dhermawana dkk / Jurnal IImiah Teknik Mesin, Elektro dan Komputer Vol 1 No. 3 (2021) 45 - 57

\begin{tabular}{|ll|}
\hline Project Name: & sisfo_psb \\
Project Path: & f:lpsb_webl \\
Chart File: & sisfo_ps .dfd \\
Chart Name: & Yourdon - Context Diagram \\
Created On: & Jan-06-2011 \\
Created By: & haris \\
Modified On: & Mar-26-2011 \\
Modified By: & haris
\end{tabular}

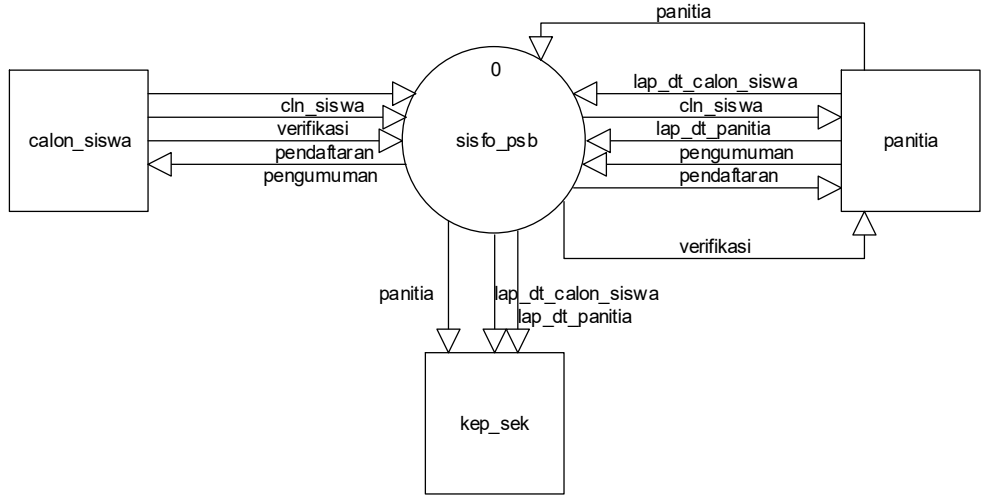

Gambar 2 Context Diagram

\subsection{Perancangan}

a. Desain Halaman Utama

Halaman utama dari Sistem Informasi Pemesanan Barang Berbasis WAP. Menampilkan halaman WAP dengan tampilan selamat datang di layanan pemesanan notebook di Podomoro Notebook.

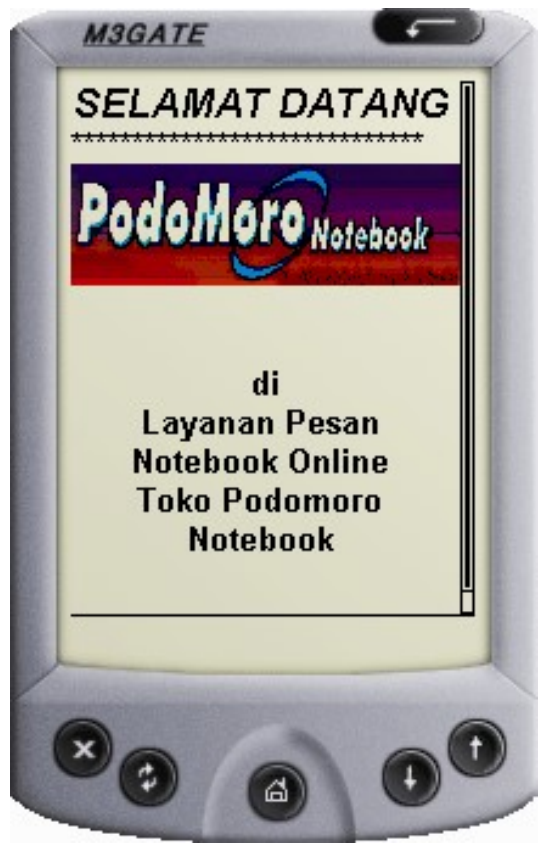

Gambar 3 desain halaman utama

b. Halaman Menu Utama 
*Iman Dhermawana dkk / Jurnal Ilmiah Teknik Mesin, Elektro dan Komputer Vol 1 No. 3 (2021) 45 - 57

Halaman menu utama menampilkan halaman yang berisikan profil, cara pesan, cara pembayaran, registrasi, produk notebook, login.

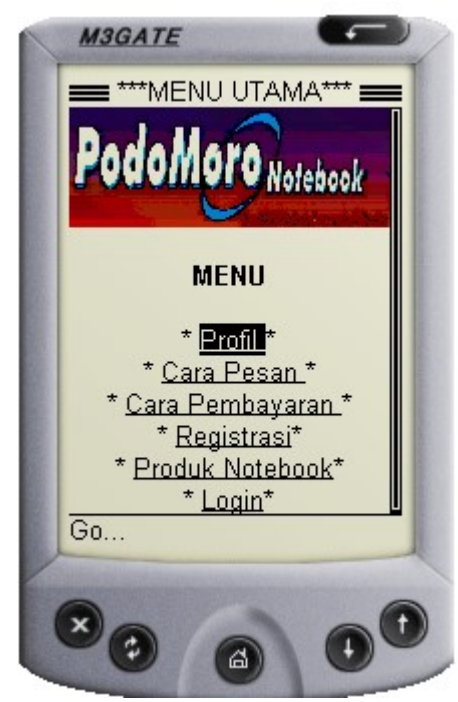

Gambar 4 halaman menu utama

1. Desain Melihat Profil Toko

Halaman melihat profil toko berisi penjelasan - penjelasan tentang toko dan produk yg ditawarkan.

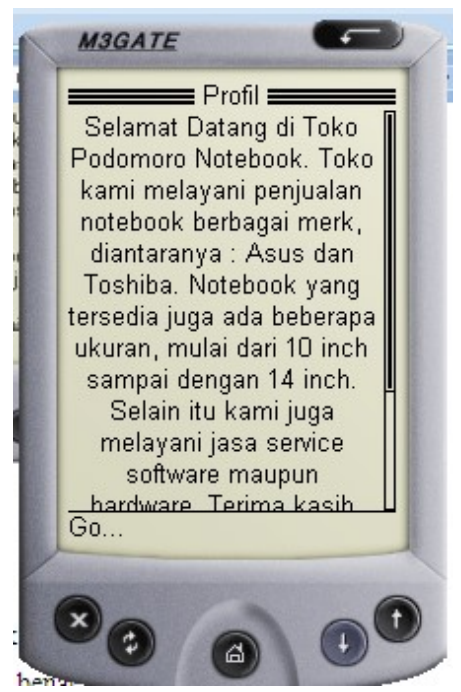

Gambar 5 halaman profil

\section{Hasil dan Pembahasan}

1. Desain Halaman Utama

Halaman utama dari Sistem Informasi Pemesanan Barang Berbasis WAP. Menampilkan halaman WAP dengan tampilan selamat datang di layanan pemesanan notebook di Podomoro Notebook.

JURNAL ILMIAH TEKNIK MESIN, ELEKTRO DAN KOMPUTER Vol.1, No.3, November 2021, pp. 45 - 57 


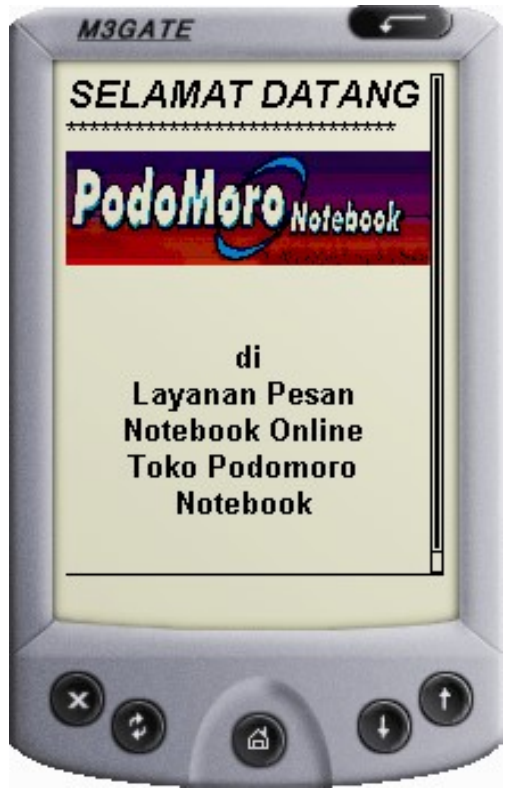

Gambar 6 desain halaman utama

2. Halaman Menu Utama

Halaman menu utama menampilkan halaman yang berisikan profil, cara pesan, cara pembayaran, registrasi, produk notebook, login.

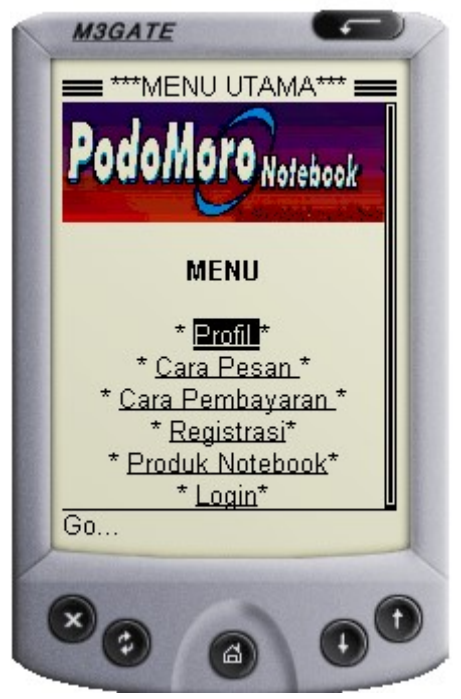

Gambar 7 halaman menu utama

3. Desain Melihat Profil Toko

Halaman melihat profil toko berisi penjelasan - penjelasan tentang toko dan produk yg ditawarkan. 
4. Desain Cara Pesan

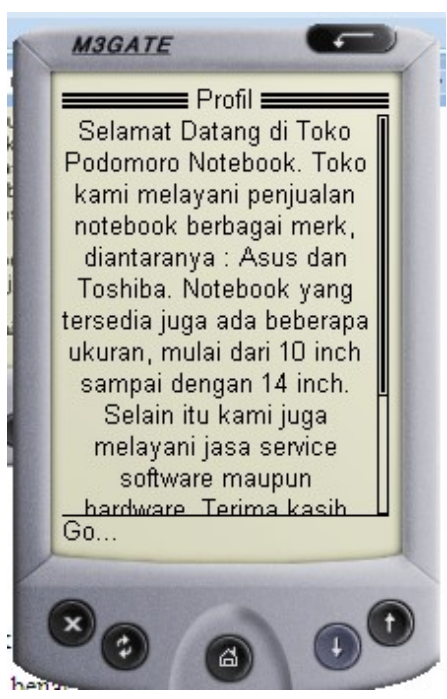

Gambar 8 halaman profil

Halaman cara pesan berisi tentang langkah-langkah dalam melakukan pemesanan notebook.

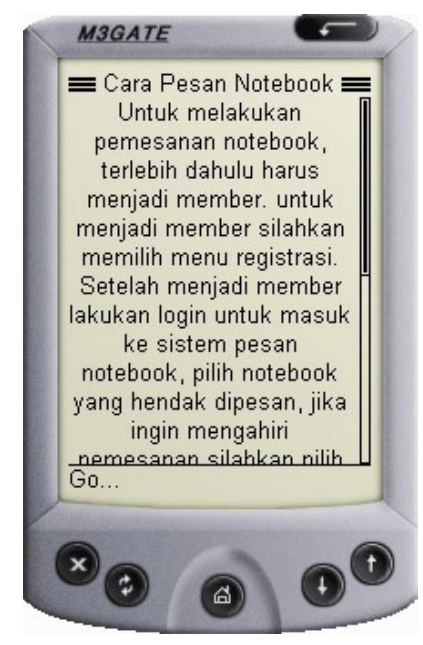

Gambar 9 halaman cara pesan

5. Desain halaman registrasi

Halaman ini berisi form registrasi untuk menjadi member, dengan cara memasukkan identitas diri dengan benar. 


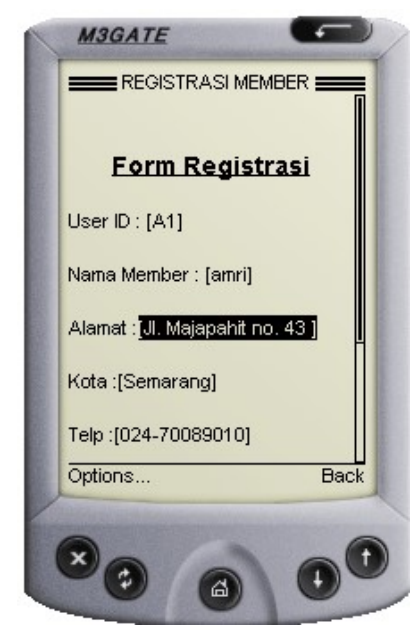

Gambar 10 halaman form registrasi

6. Desain form daftar member

Setelah mengisi data member pada halaman WAP maka data tersebut akan tersimpan di halaman member pada administrator.

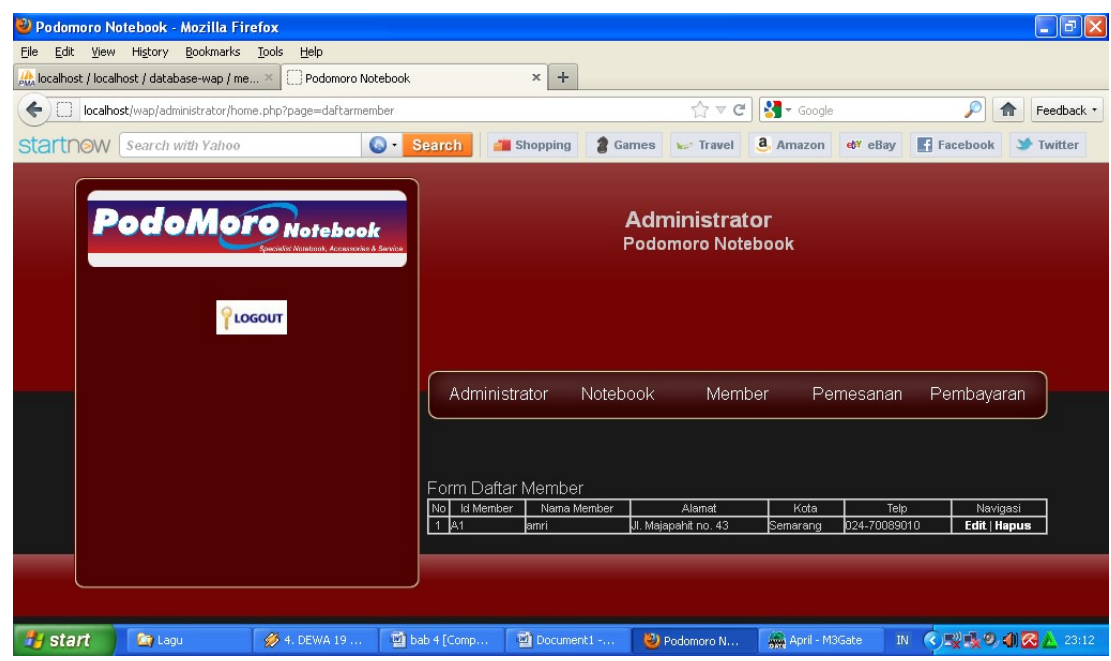

Gambar 11 halaman form daftar member

7. Desain halaman form input barang Sebelum user melihat stok barang pada Toko Podomoro Notebook, pihak admin harus mengisi terlebih dahulu barang yang akan ditawarkan. 
8.

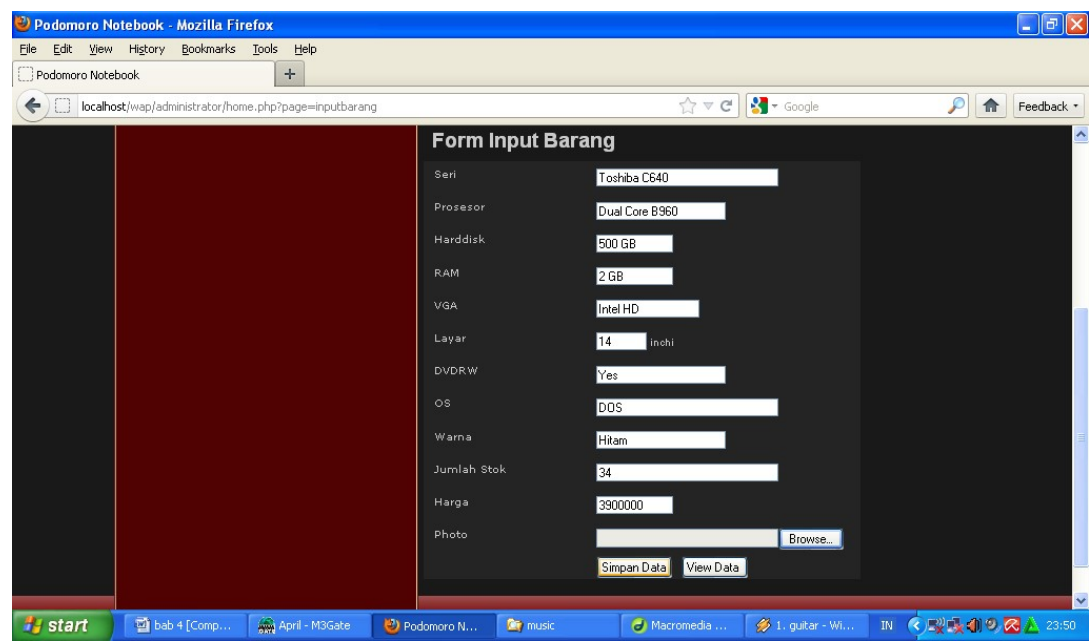

Gambar 12 halaman daftar notebook

9. Desain Halaman Login

Halaman ini berisikan form login untuk member yang akan masuk ke dalam sistem pemesanan notebook di Podomoro Notebook.

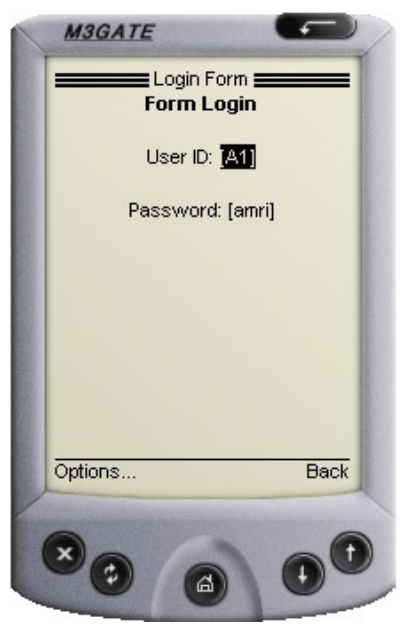

Gambar 13 halaman login

10. Desain Menu Transaksi

Pada halaman menu transaksi terdapat menu pesan notebook, keranjang belanja, konfirmasi pembayaran, dan menu logout. 


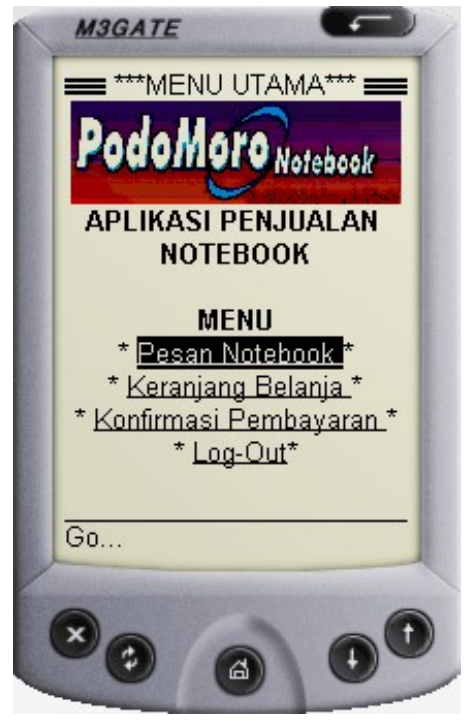

Gambar 14 desain menu transaksi

11. Desain form pembayaran

Setelah mengkonfirmasi pembayaran pada form pembayaran di halaman WAP maka data tersebut akan tersimpan di form pembayaran pada halaman admin.

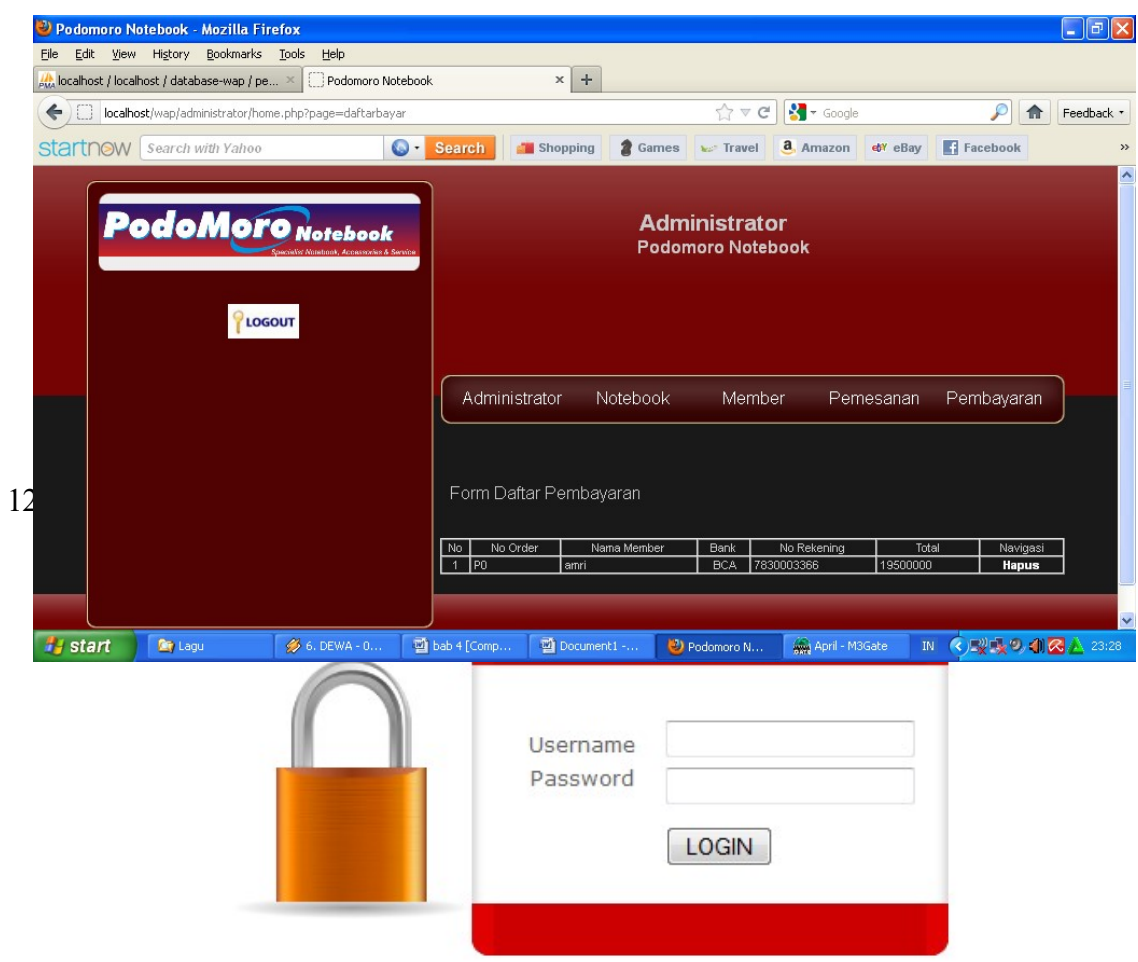

Gambar 15 halaman login administrasi 
13. Desain Menu Administrasi

Menu Administrasi berisi menu master yaitu, administrator, notebook, member, pemesanan, pembayaran.

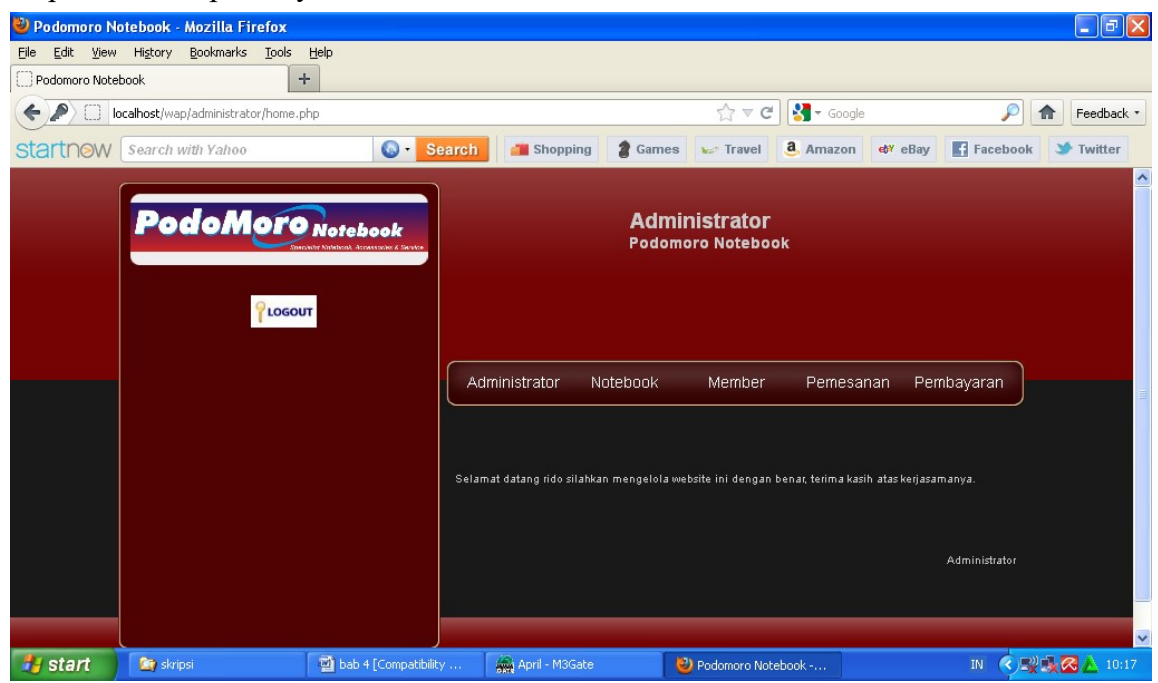

Gambar 16 desain halaman administrator

14. Desain Menu Tambah Administrator

Halaman ini berisikan tentang form tambah user untuk administrator.

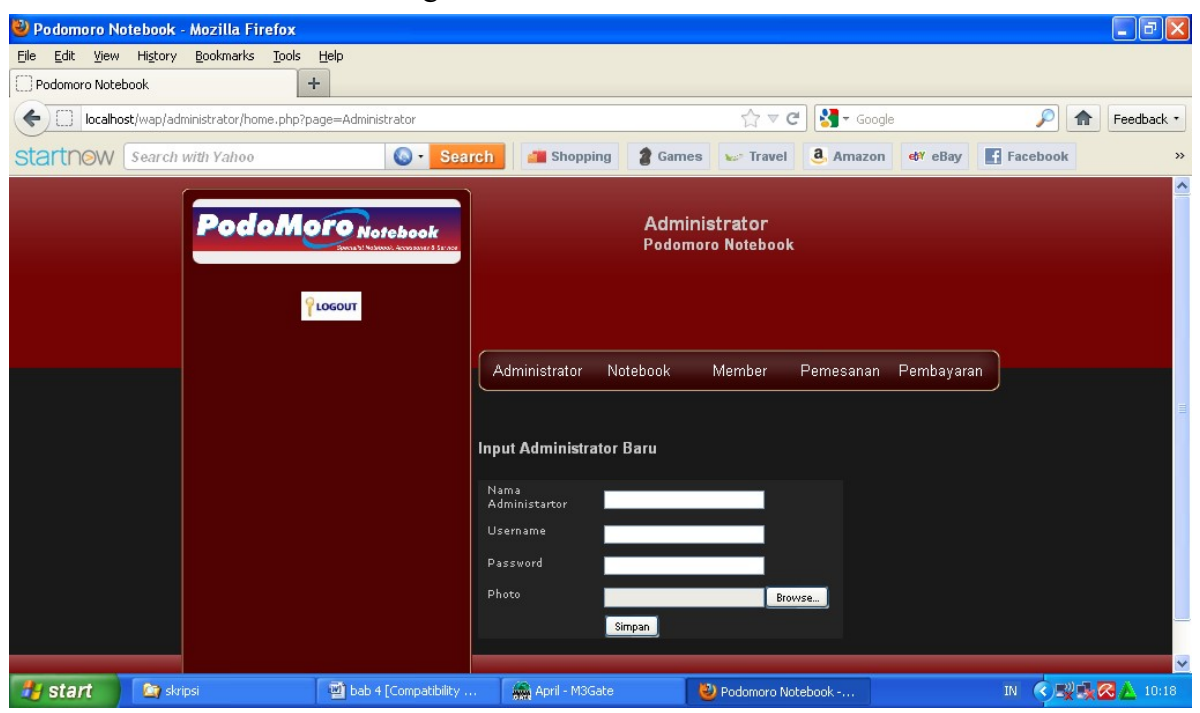

Gambar 17 desain input administrator

\section{Kesimpulan}

Dari hasil penelitian dan analisa sistem lama, kemudian dikembangkan ke dalam sistem baru yang dituangkan dalam penyusunan skripsi ini, maka dapat ditarik kesimpulan sebagai berikut :

JURNAL ILMIAH TEKNIK MESIN, ELEKTRO DAN KOMPUTER Vol.1, No.3, November 2021, pp. 45 - 57 
*Iman Dhermawana dkk / Jurnal IImiah Teknik Mesin, Elektro dan Komputer Vol 1 No. 3 (2021) 45 - 57

1. Sistem yang dilakukan dalam penerimaan siswa baru di SMK Negeri 4 Kendal masih menggunakan sistem konvensional.

2. Kelemahan pada sistem penerimaan siswa baru secara konvensinal yaitu seperti terjadinya antrian pada saat penerimaan siswa baru.

3. Bagi calon siswa yang tinggal jauh dari lokasi sekolah merupakan kendala tersendiri, selain itu calon siswa yang ingin mendapatkan informasi jurnal penerimaan siswa baru harus datang langsung ke sekolah.

4. Dengan adanya sistem penerimaan siswa baru online diharapkan dapat memecahkan masalah yang terjadi pada saat penerimaan siswa baru di SMK Negeri 4 Kendal.

\section{Daftar Pustaka}

Agus, M. 2008, Internet, Gramedia, Jakarta.

Amsyah, Zulkifli. 2001, Manajemen Sistem Informasi, PT. Gramedia Pustaka Utama, Jakarta

Davis,Gordon B. 1999, Sistem Informasi Manajemen, PT. Pustaka Pressindo, Jakarta.

Dwidjanto, Teguh.2010, Pedoman pelaksanaan penerimaan peserta didik baru di lingkungan pembinaan dinas pendidikan pemuda dan olahraga kabupaten kendal, Dinas Pendidikan Pemuda dan Olahraga Kabupaten Kendal, Kendal.

Juju, Dominikus dan Syukrie Muhammad. 2009, Jurus Jitu Pembuatan Web Free Lance, PT. Elex Media Komputindo, Jakarta.

Musyawarah, Rina. 2005, Membangun Apilikasi Database Berbasis Web Untuk Pemula, PT. Elex Media Komputindo, Jakarta.

Rafiza, H. 2006, Panduan dan Referensi Kamus Fungsi PHP 5, PT. Elex Media Komputindo, Jakarta.

Soeherman, Bonnie. \& Pinontoan, Marion. 2008, Designing Information System, PT.Elex Media Komputindo, Jakarta.

Supriansyah, Haris. \& Kartoyo. 2007, 30 menit Menjadi Web Master, OASE Mata Air Makna, Bandung. Sutarman. 2008, Membangun Aplikasi Web dengan PHP dan MySQL, Graha Ilmu, Yogyakarta.

Undang-undang Republik Indonesia Nomor 20 tahun 2003 tentang sisdiknas, Citra Umbara, Bandung.

Wahyono, Teguh. 2005, Pemrograman Web Dinamis, PT. Elex Media Komputindo, Jakarta.

Yuhefizar. 2008, 10 Jam Menguasai Internet: Teknologi dan Aplikasinya, PT. Elex Media Komputindo, Jakarta.

Zaki, A. 2008, PHP dan MySQL, PT. Gramedia Pustaka Utama, Jakarta. 